\title{
Evaluation of the Source and Amount of Energy Use for Groundnut Processing in Nasarawa State of Nigeria
}

\author{
Emmanuel Ademola Adekunle ${ }^{1}$, Abdulrafiu Tayo Yusuf ${ }^{2}$, Oreoluwa Busola Ajayi ${ }^{3}$, \\ Afolake Esther Agboola ${ }^{4}$, Odunayo James Rotowa ${ }^{5, *}$ \\ ${ }^{1}$ Department of Agricultural Economic, Faculty of Agriculture, University of Abuja, Abuja, Nigeria \\ ${ }^{2}$ Department of Agricultural Economics and Extension, Faculty of Agriculture, Federal University of Lafia, Lafia, Nigeria \\ ${ }^{3}$ Department of Forest Products Development and Utilisation, Forestry Research Institute of Nigeria, Ibadan, Nigeria \\ ${ }^{4}$ Department of Agricultural Technology, Federal College of Forestry, Ibadan, Nigeria \\ ${ }^{5}$ Department of Forestry and Wildlife Management, Faculty of Agriculture, Nasarawa State University, Shabu-Lafia, Nasarawa, Nigeria
}

Email address:

odunrotowa@yahoo.com (O. J. Rotowa), babaaru92@gmail.com (O. J. Rotowa)

*Corresponding author

\section{To cite this article:}

Emmanuel Ademola Adekunle, Abdulrafiu Tayo Yusuf, Oreoluwa Busola Ajayi, Afolake Esther Agboola, Odunayo James Rotowa. Evaluation of the Source and Amount of Energy Use for Groundnut Processing in Nasarawa State of Nigeria. Journal of Energy, Environmental \& Chemical Engineering. Vol. 5, No. 3, 2020, pp. 36-41. doi: 10.11648/j.jeece.20200503.11

Received: September 9, 2020; Accepted: September 21, 2020; Published: October 7, 2020

\begin{abstract}
A study was carried out to analyze the sources and amount of energy consumed for groundnut processing in Nasarawa-Eggon Local Government of Nasarawa State with the aim to determine the energy use pattern, the relationship between energy inputs and outputs and to determine the productivity of energy use in groundnut processing. A total of 100 Groundnut processors were identified and 50 processors were randomly sampled for the study. Data was collected through the use of structured questionnaire on inputs and outputs in groundnut processing. Data was collected once a week from each processor for a period of six weeks. Collected data were analysed using descriptive statistics, production function analysis and correlation analysis. The result revealed that the circle of groundnut production is completed in 4 days. Groundnut processing in the study area is mainly dependent on direct, indirect and renewable energy forms especially fuelwood which accounts for $75.04 \%$ of the daily total energy used and the total amount of energy used for processing groundnut on a daily basic is $1410.42 \mathrm{MJ}$ and all forms of energy had direct relationship with processed groundnut output. The result of daily energy inputs and outputs shows that the quantity of raw Groundnut processed daily range from $70 \mathrm{~kg}$ to $280 \mathrm{~kg}$ with an average of $165.2 \mathrm{~kg}$ which is equal to $1372.8 \mathrm{MJ}$ of energy equivalent and that an average of 6 machine hours, 32 liters of water were used and 58.8 $\mathrm{Kg}$ of fuel wood were also used. It was therefore recommendations that more labour and fuel efficient Groundnut processing machines be introduced to enhance energy productivity in groundnut processing and save cost and that sustainable alternatives energy such as briquette be exploited instead of fuelwood.
\end{abstract}

Keywords: Fuelwood, Energy, Groundnut Processing, Production and Labour

\section{Introduction}

Energy is said to be the engine for growth and development in all economies of the world. In all parts of the world today, the demand for energy is increasing almost on daily basis. According to Pimental [1], energy is one of the most valuable inputs in agricultural production. It is invested in various forms such as mechanical (human labor, animal draft), chemical (fertilizer, pesticides, herbicides) and electrical. The amount of energy used in agricultural production, processing and distribution is significantly high in order to feed the expanding population and to meet other social and economic goals of a society. Sufficient availability of the right energy and their effective and efficient uses are prerequisites for improved agricultural production $[1,2]$. Effective energy use in agriculture is one of the conditions 
for sustainable agricultural production, since it provides financial savings, fossil resources preservation and air pollution reduction. Energy use in the agricultural sector depends on the size of the population engaged in agriculture, the amount of arable land and the level of mechanization. The scarcity of energy on one hand, and the importance of agriculture to feed the world on the other hand lead a lot of researchers to evaluate the amount of energy use in agricultural production and processing. Nevertheless, it seems that energy input analysis in agricultural sector is much more difficult than other sectors like industry, since the conditions and parameters affecting the agricultural productions are variable [3]. The share of energy in agricultural production expenses varies widely by activity, production practice, processing practice and locality. Energy in various forms is necessary inputs for Groundnut processing.

\subsection{Energy Forms and Agro-processing}

Energy analysis can be divided into two parts as direct and indirect energy. Direct energy is directly used at the farm and on the field for crops examples are human labour, diesel, electricity, water etc but indirect energy is not directly consumed at the farm, examples are raw Groundnut and machinery. However both direct and indirect forms of energy are required for agricultural processing in terms of growth and development [4]. Renewable energy is energy that is naturally replaced or controlled carefully and therefore can be used without the risk of finishing it all; examples are water, human labour etc. Non-Renewable energy are energy that cannot be replaced or controlled carefully once it is used, examples are electricity, diesel etc.

Agro-processing industries refers to those activities that transform agricultural commodities into different forms that add value to the product post-harvest technology includes; selection, preservation, packaging and processing has contributed to the promotion of agricultural production through the improvement of farmers' income by raising the value of agricultural produce [5]. The success in Africa's effort in achieving the stated objective for food security achievement will depend on the parallel development of agro-industries, appropriate physical and institutional infrastructure, agricultural capacity building and improved macro-economic management [6].

\subsection{The Benefits of Agro-Processing Activities}

The benefit of agro processing activities may be itemized as follows according to Isitor et al and Kachru [7, 8] Processing of agricultural commodities, especially those which are seasonal and perishable will increase their availability; reduce food export, there-by improving the declining trend in self-sufficiency as well as providing better market opportunities.

1) Improves quality of produce and quantity of technology for loss preservation

2) Better economic utilization of agricultural residue by products and recycling of waste.

3) Generation of rural and urban employment and source of income to the economy.

4) Post-harvest processing adds value and helps improve income for both farmers and non-farm enterprise.

5) Enhancement of shelf life of the produce, storage/packaging and development of better performing materials

6) Development of new products and processes for nutrition, convenience and taste; products that need to be processed into forms as desired by consumers usually attract higher marketing margins.

7) Agro-processing helps to increase export competitiveness of the agricultural sector.

Groundnut (Arachis hypogea L.) otherwise called peanut, monkey nut, gobber pea and arachide belongs to the family leguminosea. It originated from Latin America and the Portuguese who were responsible for its introduction into West Africa from Brazil in the 16th Century [9, 10] Peanut is one of the most popular commercial crops in Nigeria. Nigeria produces $41 \%$ of the total Groundnut production in West Africa [11]. It is cultivated for its kernels, the oil and hay for livestock. Groundnut cake is often deep fired or dried to make a snack locally called "kuli-kuli". Groundnut flour is used as an ingredient in soups, sweet, confectionaries and puddings. Groundnut especially those produced in developing countries has been used traditionally since the origin of humanity. It is rich in oil and protein and has a high energy value. Developing countries account for nearly 95 percent of world production [11]. Asia accounts for about $70 \%$ of this amount while the major producers, India and China together represent over two-thirds of global output. Other important producers of Groundnut are: Nigeria, Senegal, Sudan and Argentina. Groundnut with $25 \%$ protein and more than $40 \%$ oil is an important food crop in many areas of semi-arid tropics [12]. In Nigeria, the processing of Groundnut into various products is mostly done by women either for home consumption or for commercial purposes [13]. The most common commercial products of Groundnut are: Groundnut oil, Groundnut cake and fried peanuts which are sold at market places or hawked on the streets [14]. The processing of Groundnut is both the source of income and employment to a large proportion of rural women in northern Nigeria.

Several researchers have conducted studies on energy consumption for the different agricultural processes in Nigeria such as [15-18]. Effective energy use in agriculture is one of the conditions for sustainable agricultural production, since it provides financial savings, fossil resources preservation and air pollution reduction and bio-oil [19]. This study therefore analyze the energy use for groundnut processing in Nasarawa Eggon Local Government of Nasarawa State with the aim to determine the energy use pattern, the relationship between energy inputs and outputs and to determine the productivity of energy use in Groundnut 
processing

\section{Methodology}

\subsection{The Study Area, Sampling Technique and Sample Size}

The study was carried out in Nassarawa-Eggon local government area of Nasarawa State. Nasarawa-Eggon, the traditional headquarters of the Eggon people, covering an estimated land mass of about $2035 \mathrm{~km}^{2}$ with $70 \%$ of the residents as subsistence farmers who cultivate crops such as yam, maize, sorghum, millet, cowpea and Groundnut. The area lies approximately between latitude $70^{\circ}$ and $90^{\circ}$ North and longitude $70^{\circ}$ and $100^{\circ}$. Reconnaissance survey was conducted, to identify the locations and number of Groundnut processors within Nassarawa-Eggon town with deliberate consideration of the energy source for processing. From the survey, a total of 100 Groundnut processors were identified and 50 processors were randomly sampled for the study.

\subsection{Data Collection and Analytical Technique}

Data was collected through the use of structured questionnaire administered to the respondents. Data was collected on inputs (raw Groundnut, fuelwood, diesel, water, electricity, machine, human labour) and outputs (Groundnut cake and oil) in groundnut processing. Each sampled groundnut processor in the study area was tagged and data was collected once a week for a period of six weeks. Descriptive statistics, (frequency counts, percentages mean) production function analysis and correlation analysis were used to achieve objectives. Three functional forms of the model were fitted into data and the linear model was selected for result discussion based on: coefficient of multiple determination $\mathrm{R}^{2}$, expected signs of the regression coefficient and number of significant variable ( $\mathrm{t}$-value). The implicit form of the production is specified as:

$$
\mathrm{Y}=\mathrm{a}+\beta_{1} \mathrm{X}_{1}+\beta_{2} \mathrm{X}_{2}+\beta_{3} \mathrm{X}_{3}+\beta_{4} \mathrm{X}_{4}+\beta_{5} \mathrm{X}_{5}+\mathrm{U}
$$

Where; $\quad \mathrm{Y}=$ Processed Groundnut, $\mathrm{X}_{1}=$ Electricity, $\mathrm{X}_{2}=$ Human labour $\mathrm{X}_{3}=$ Machinery $\mathrm{X}_{4}=$ Diesel, $\mathrm{X}_{5}=$ Water, $\mathrm{X}_{6}=$ Raw Groundnut $(\mathrm{Kg}), \mathrm{X}_{7}=$ Firewood, $\mathrm{a}=$ Constant term, $\mathrm{U}=$ error term.

Correlation Analysis was estimated using

$$
\mathrm{r}=\frac{1 \sum X_{i} Y}{n-i \sqrt{\left(\sum X_{i}^{2}\right)\left(\sum Y^{2}\right)}}
$$

$\mathrm{Y}=$ Output of processed Groundnut (\#), $\mathrm{X}_{1}=$ Indirect energy (machinery), $\mathrm{X}_{2}=$ Direct energy (water, diesel, electricity, human labour), $\mathrm{X}_{3}=$ Renewable energy (water, human labour, electricity), $\mathrm{X}_{4}=$ Non-renewable energy (machinery, diesel)

Energy Productivity $=\frac{\text { output of processed Groundnut }(\text { Cake and oil)(\$) }}{\text { input }(\text { Energy }+ \text { Labour+Materials })}(3)$

The inputs used in groundnut processing and the outputs were converted into energy equivalent units using the conversion factors (Table 1).

Table 1. Energy Equivalent for different inputs and outputs in groundnut processing.

\begin{tabular}{lll}
\hline Input & Energy Equivalent (MJ/unit & Source \\
\hline Human labour (Mhr) & 1.96 & {$[20]$} \\
Machinery $(\mathrm{Hr})$ & 13.06 & {$[20]$} \\
Diesel oil (L) & 56.31 & {$[20]$} \\
Groundnut seed $(\mathrm{Kg})$ & 8.31 & {$[21]$} \\
Groundnut oil (L) & 1.31 & {$[21]$} \\
Groundnut cake $(\mathrm{Kg})$ & 8.31 & {$[21]$} \\
Electricity $(\mathrm{Kw})$ & 10.59 & {$[22]$} \\
Water $(\mathrm{L})$ & 0.63 & {$[22]$} \\
Fuelwood $(\mathrm{Kg})$ & 18.00 & {$[22]$} \\
\hline
\end{tabular}

\section{Results}

\subsection{Daily Inputs and Outputs Level for Groundnut Processing Per Processing Circle}

Circle of groundnut production is completed in 4 days. The daily energy inputs and outputs in groundnut processing are presented in Table 2. The result shows that the quantity of raw Groundnut processed daily range from $70 \mathrm{~kg}$ to $280 \mathrm{~kg}$ with an average of $165.2 \mathrm{~kg}$ which is equal to $1372.8 \mathrm{MJ}$ of energy equivalent. The $165.2 \mathrm{~kg}$ reported in this study is higher than $154.5120 \mathrm{~kg}$ reported by [24] in groundnut processed in a processing cycle of about 4 days in middlebelt Nigeria, The result also reveals that the quantity of labour used range from $5 \mathrm{Man} / \mathrm{hrs}$ to $12 \mathrm{Man} / \mathrm{hrs}$ with an average of $8.65 \mathrm{Man} / \mathrm{hrs}$ which in the energy equivalent is equal to $16.95 \mathrm{MJ}$. The average quantity of diesel used 2.6 liters in energy equivalent was $146.41 \mathrm{MJ}$, while an average of $8.52 \mathrm{KW}$ of electricity equivalent to $90.23 \mathrm{MJ}$ of energy. [25] Calculated the average energy consumption of each input and output to be $19248.04 \mathrm{MJ}$ ha- 1 and $3488.39 \mathrm{~kg}$ ha1 , respectively in a study on energy use pattern and sensitivity analysis of energy inputs and economical models for peanut production in Iran.

The result also shows that an average of 6 machine hours, 32 liters of water were used and $58.8 \mathrm{Kg}$ of fuel wood were also used. This corresponds to $78.36 \mathrm{MJ}, 20.16 \mathrm{MJ}$ and 1058.4 MJ of energy respectively. On a daily basis, the average amount of energy used in processing groundnut is $1147.01 \mathrm{MJ}$ of energy (Table 2). [26] Calculated the energy inputs for cotton production in Turkey at $49736.9 \mathrm{MJ}$ ha-1. In some related studies total energy input has been reported as 11366.2MJ ha-1 for maize productions [27], $18931.09 \mathrm{MJ}$ ha-1 for sunflower [28], 35372.23 MJ ha-1 for soybean productions [29] and about $810570 \mathrm{MJ}$ ha-1 for alfalfa [30]

\subsection{Energy Use Pattern in Groundnut Processing}

The energy consumption pattern for processed groundnut is presented in Table 3. The average daily energy used for groundnut processed is $1410.42 \mathrm{MJ} /$ process circle. With fuelwood having the highest percentage consumption $75.04 \%$, followed by diesel $(10.38 \%)$ the least energy source was recorded in water with percentage value of $1.43 \%$, 
fuelwood energy had a significant share $(75.04 \%)$. This is because the processors centers uses fuelwood harvested from farms and nearby forest to fry groundnut cake. On a daily basis, a total of $1410.42 \mathrm{MJ}$ of energy was recorded to be consumed for groundnut production (Table 2) a scenario similar to the findings of $[31,22,32,33,15]$ they conducted similar work for different types of crops in different parts of the world.

\subsection{Energy Forms in Groundnut Processing}

The share of direct energy used in groundnut processing was $13317.12(94.44 \%)$, while indirect energy forms amounted for 783.60 (5.56\%). This corroborate the report of [33] on the Energy use Efficiency for Groundnut Production in a Semi-mechanized Cultivation System that the shares of direct energy used for semi-mechanized groundnut production exceeds that of the indirect energy where indirect energy input shares were $53.80 \%$ and $46.20 \%$ in the total energy input and implies that the energy inputs of human labour, diesel fuel, and electricity was more than the total energy input of machinery, fertilizers, chemicals, and seed.
On the other hand, renewable and non-renewable forms contributed 10955.14 (77.92\%) and 13733.48 (22.08\%) respectively to the total energy used for processing. The high share of direct energy form was due to the fact that machine (which is a source of indirect) energy accounted for only $5.56 \%$ of the total energy of both direct and indirect energy consumed. The share of renewable energy was higher than the non-renewable energy forms; indicating that groundnut processing in the study area is dependent mainly on renewable forms of energy especially fuelwood. This is in contrast with the report of some researchers who reported that the share of non-renewable energy is greater than that of renewable energy consumption [34-36]. Dependence on fuelwood for processing can be as a result of the proximity of the processing centers to farms and nearby forest and this is not sustainable in the long run as it leads to deforestation, global warming and climate change (Table 4). Similar trends were obtained for renewable and non-renewable energy input shares in wheat, bean, lentil, and chick pea production in Iran and cotton production in Turkey [37-39].

Table 2. Daily energy inputs and outputs in groundnut processing per process.

\begin{tabular}{|c|c|c|c|c|c|c|c|c|c|c|c|c|c|c|c|c|c|c|c|}
\hline & \multicolumn{2}{|c|}{$\begin{array}{l}\text { Raw } \\
\text { Groundnut }\end{array}$} & \multicolumn{2}{|c|}{ Human labour } & \multicolumn{2}{|c|}{ Electricity } & \multicolumn{2}{|c|}{ Machine } & \multicolumn{2}{|c|}{ Water } & \multicolumn{2}{|c|}{ Fuel wood } & \multicolumn{2}{|c|}{ Diesel } & \multicolumn{2}{|l|}{ Cake } & \multicolumn{2}{|l|}{ Oil } & \multirow{2}{*}{$\begin{array}{l}\text { Total } \\
\text { output } \\
\text { MJ } \\
\end{array}$} \\
\hline & $\mathbf{K g}$ & MJ & ManHr & MJ & $\mathbf{K w}$ & MJ & $\mathrm{Hr}$ & MJ & $\mathbf{L}$ & MJ & Kg & MJ & $\mathbf{L}$ & MJ & Kg & MJ & $\mathbf{L}$ & MJ & \\
\hline Minimum & 70 & 581.7 & 5 & 9.8 & 10.78 & 114.05 & 6 & 78.36 & 10 & 6.30 & 24.5 & 441 & 3 & 168.93 & 63 & 523.53 & 20 & 13.4 & 536.93 \\
\hline Maximum & 280 & 2326.8 & 12 & 23.52 & 15.10 & 159.76 & 12 & 156.72 & 60 & 37.8 & 98 & 1764 & 6 & 337.86 & 294 & 2443.14 & 80 & 53.6 & 2496.74 \\
\hline Average & 165.2 & 1372.8 & 8.65 & 16.95 & 8.52 & 90.23 & 6 & 78.36 & 32 & 20.16 & 58.8 & 1058.4 & 2.6 & 146.41 & 134.4 & 1116.86 & 45.00 & 30.15 & 1147.01 \\
\hline
\end{tabular}

Table 3. Energy Use pattern for Groundnut processing.

\begin{tabular}{llll}
\hline Input & $\begin{array}{l}\text { Daily average } \\
\text { per process }\end{array}$ & $\begin{array}{l}\text { Energy } \\
\text { equivalent }\end{array}$ & $\begin{array}{l}\text { Percentage } \\
(\%)\end{array}$ \\
\hline Water (L) & 32 & 20.16 & 1.43 \\
Diesel (L) & 2.6 & 146.41 & 10.38 \\
Labour (Mhr) & 8.52 & 16.95 & 1.20 \\
Electricity (Kw) & 8.52 & 90.14 & 6.39 \\
Machinery (Hr) & 6 & 78.36 & 5.56 \\
Fuelwood (Kg) & 58.8 & 1058.40 & 75.04 \\
Total energy input & - & 1410.42 & 100 \\
\hline
\end{tabular}

Table 4. Total energy input in form of direct, indirect and renewable and non-renewable energy for Groundnut processing.

\begin{tabular}{|c|c|c|}
\hline Energy forms & Total energy input & Percentage (\%) \\
\hline Direct energy $^{a}$ & 13317.12 & 94.44 \\
\hline Indirect energy ${ }^{b}$ & 783.60 & 5.56 \\
\hline Total & 14100.72 & 100.00 \\
\hline Renewable energy $^{c}$ & 10955.14 & 77.92 \\
\hline Non-renewable ${ }^{d}$ & 13733.48 & 22.08 \\
\hline Total & 14059.64 & 100.00 \\
\hline
\end{tabular}

Water, diesel, electricity, fuelwood and human labour, b-machinery, c- Water and human labour, Electricity, fuel wood, d-, machinery, diesel.

\subsection{Relationship Between Energy Inputs and Output in Groundnut Processing}

A linear relationship between total energy input and output in was obtained with values $\mathrm{R} 2=0.93$ which indicated that groundnut crop yield is dependent on energy input. This implies that $94 \%$ of the variation in output of processed groundnut was explained by the energy input included. Abubakar and Hamed [15] also reported a linear relationship between total energy input and output with values $\mathrm{R} 2=0.88$ in millet, which indicated that millet crop yield is also dependent on energy input. The result shows that fuelwood, raw groundnut and water variables are significant at $\mathrm{P}>0.01$ and $\mathrm{P}>0.10$ respectively as they positively influence processed groundnut (Table 5). The result of the relationship between energy forms and processed groundnut output shows that the direct, indirect and renewable forms of energy are significant at $\mathrm{P}>0.01$ and $\mathrm{P}>0.05$ respectively. This implies that processed groundnut output is sourly dependent on direct, indirect and renewable forms of energy (Table 5)

The result of energy input for the production of processed groundnut shows that the energy input for the production of processed groundnut ranges from 26.38 /MJ to 1647.49 \#/MJ. However, the energy productivity for all the input was 19.80 /MJ. The most productive input was found out to be the number of Man-hours used and the least was quantity of fuelwood used. This implies that an increase in the number of man-hours will lead to an increase in processed groundnut output. Energy productivity was 19.80 /MJ which mean $1 \mathrm{MJ}$ of energy will produce 19.80 /MJ of processed groundnut (Table 5). 
Table 5. Relationship between energy input and processed Groundnut.

\begin{tabular}{lll}
\hline Coefficient Variable & $\mathbf{B}$ & $\mathbf{R}^{-2}$ \\
\hline Constant & $-1.1321 .121-1.010^{\mathrm{ns}}$ & \\
Diesel $\left(\mathrm{X}_{1}\right)$ & $0.0330 .0311 .075^{\mathrm{ns}}$ & \\
Fuelwood $\left(\mathrm{X}_{2}\right)$ & $3.7090,6875,318^{* * *}$ & \\
Water $\left(\mathrm{X}_{3}\right)$ & $-0.7830 .169-4.696^{* * *}$ & \\
Machinery $\left(\mathrm{X}_{4}\right)$ & $-0.0380 .376-0.102^{\mathrm{ns}}$ & \\
Electricity $\left(\mathrm{X}_{5}\right)$ & $0.0340 .2570 .927^{\mathrm{ns}}$ & \\
Labour $\left(\mathrm{X}_{6}\right)$ & $-0.5090 .386-1.319^{\mathrm{ns}}$ & \\
Raw Groundnut $\left(\mathrm{X}_{7}\right)$ & $-1.9470 .603-3.230^{*}$ & 0.94 \\
Energy forms & Correlation coefficient & \\
Indirect energy & $0.660^{* *}$ & \\
Direct energy & $-0.846^{* * *}$ & \\
Renewable energy & $0.877^{* * *}$ & \\
Non-renewable energy & $0.393^{\mathrm{NS}}$ & \\
& Daily average per & equivalent Energy \\
Input & process Energy & productivity (A/MJ) \\
Water (Lt) & 3220.16 & 1396.25 \\
Diesel (Lt) & 2.6 & $146.41 / 190.73$ \\
Labour (mhr) & 8.6516 .95 & 1647.49 \\
Electricity (Kw) & 8.52 & $90.14 / 309.80$ \\
Machinery (hr) & 678.36 & 356.37 \\
Fuelwood (kg) & 58.8 & 1058.40 \\
Total energy input $(\mathrm{MJ})$ & 410.42 & 19.80 \\
Groundnut output (N) & 27925 & \\
\hline
\end{tabular}

$* * *=$ Significant at $1 \%, * *=$ Significant at $5 \%, *=$ Significant at $10 \%$, ns $=$ Not Significant.

\section{Conclusion and Recommendations}

\subsection{Conclusion}

The result revealed that groundnut processing in the study area is mainly dependent on direct, indirect and renewable energy forms especially fuelwood. Fuelwood accounts for $75.04 \%$ of the daily total energy used and the total amount of energy used for processing groundnut on a daily basis is $1410.42 \mathrm{MJ}$, it was noted that all forms of energy had direct relationship with the output of the processed groundnut.

\subsection{Recommendations}

Based on the result of the study, It is recommendations that;

i. More potential sustainable alternatives energy such as briquette be exploited instead of fuelwood.

ii. Trees should be planted around groundnut processing centers to help trap carbon emitted during the frying of the cake and mitigate climate change.

iii. There is need to introduce more labour and fuel efficient Groundnut processing machines so as to enhance energy productivity in groundnut processing and save cost,

iv. The potentials of cleaner and safer energy forms for Groundnut processing especially solar energy or improved cooking stoves should be exploited.

\section{References}

[1] Pimental D., (1992). Energy Inputs in Production Agriculture. Energy in Farm Production, Elsevier, and Amsterdam pp. 1329.
[2] Handan, A. Orhan, O. and Hatice, K. (2009). "Analysis of energy use for pomegranate production in Turkey". Journal of Food, Agriculture and Environment 7 (2): 475-48.

[3] Verma R., Singh I. P. and Sharma S. 2013. Pattern of energy utilization in groundnut cultivation in rajasthan. Indian J Econ Dev. Volume 9 No. 2 (2013): 148-159.

[4] Pathak, B. S. and Binning, A. S. (1985). Energy use pattern and potential for energy saving in rice- wheat cultivation. Agric - Energy. 4: 271-278.

[5] Akinori, N. (2006). Future Orientation of International Collaborative Research on Postharvest technology for Developing countries. Retrieved from www.rudep.org April 19, 2010.

[6] Food and Agricultural Organization, (2003). Nigeria Agribusiness sector and its support institutions. retrieved from www.fao.org April 2010.

[7] Isitor, S. U., Olukosi, J. O and Ode, M. O., (2007). Introduction to agricultural marketing and prices. Abuja: living Books 116pp.

[8] Kachru, N. P (2000). Agro-proessing industries in India Growth, status and prospects. Retrieved from www.agricoop.nic.in March 25, 2010.

[9] Gibbon, D and Pain, A. (1985). Crops of the drier region of the tropics. longman group Ltd UK pp 146 Central Nigeria.

[10] Abalu, G. O. I and Etuk, E. G. (1986). Traditional versus improved Groundnut production Practices some further evidence from Northern Nigeria. Experimental Agriculture, $22,33-38$.

[11] Echekwu, C. A and Emeka, I. (2005). Groundnut, endowing, the Groundnut /rediscovery programme in Nigeria. Opahmission Abuja pp 18.

[12] Food and Agricultural Organisation. (1994). General conclusions and recommendations of expert Dutt, B. K. (1982), Comparative efficiency of energy use in rice production energy 6: 25 .

[13] Ibrahim, D. B., Dutse, A. Y. and Hamidu, B. M. (2005). Assessment of awareness level of air and noise pollution of car transport among Motorist in Bauchimetropolis. Management Network Journal, 3, 6, 26-35.

[14] Ihekoronye, A. I. and Ngoddy, P. O (1985). Integrated, food science and technology for the Tropics. Macmillan Publishers Limited London pp 364.

[15] Abubakar, M. S and Ahmed O. (2010). Pattern of energy consumption in millet production for selected farms in Jigawa, Nigeria. Australian Journal of Basic and Applied Sciences, 4 (4): 665-672, ISSN 1991-8178.

[16] Aiyedun, P. O and B. A. Onakoya (2000). Energy Efficiency in a Private Sector - A. Paper Presented at the National Conference of Nigeria Institute of Industrial Engineers, Ibadan 9 th -11 th Nov.

[17] Ibrahim, H. Y. (2011): Energy Use Pattern in Vegetable Production Under Fadama in North.

[18] Jekayinfa S. O., and Olafimihan E. O., (2000). "A Study and Analysis of Energy Consumption in Beverage Producing Plants in Nigeria". A Paper Presented at the Annual Conference of Nigeria Institute of Industrial Engineers, Ibadan. 12th-17th, October. 
[19] Adegoke I. A and Rotowa O. J (2020). Preparation and Characterization of Bio-Oil Produced from Sawdust of Selected Wood Species. American Journal of Modern Energy. Vol. 6, No. 1, 2020, pp. 16-25. doi: 10.11648/j.ajme.20200601.13.

[20] Aboki, P. M (2015): Traditional and modern groundnut processing and marketing in north central Nigeria. A Ph. D. thesis submitted to the Department of Agricultural Economics, University of Nigeria, Nsukka pp141.

[21] FAO 2002. Groundnut: Post-harvest Operations. INPHO Postharvest Compendium 2002.

[22] Ozkan, B., H. Akcaoz, and C. Fert, 2004. Energy input-output analysis in Turkish agriculture. Renewable energy, 29: 39-51.

[23] Hussaini Y. I, Napoleon D. S and Hassan I. I (2011) An Evaluation of Groundnut Processing by Women in a Rural Area of North Central Nigeria/. Journal of Agriculture science 2 (1) 2006-2012.

[24] Ashkan Nabavi-Pelesaraei, Reza Abdi, Shahin Rafiee (2013) Energy use pattern and sensitivity analysis of energy inputs and economical models for peanut production in Iran. International Journal of Agriculture and Crop Sciences. Available online at www.ijagcs.com IJACS/2013/5-19/21932202 ISSN 2227-670X (C2013 IJACS Journal.

[25] Yilmaz I, Akcao H, Ozkan B. 2005. An analysis of energy use and input costs for cotton production in Turkey. Renew. Energy 30: 145-155.

[26] Canakci M, Topakci M, Akinci I, Ozmerzi A. 2005. Energy use pattern of some field crops and vegetable production: case study for Antalya Region, Turkey. Energy Conversion and Management 46: 655-666.

[27] Uzunoz M, Akcay Y, Esengun K. 2008. Energy input-output analysis of sunflower seed (Helianthus annuus L.) oil in Turkey. Energy Sources Part B-Economics. Planning and Policy 3: 215-223.

[28] Mousavi-Avval SH, Rafiee S, Jafari A, Mohammadi A. 2011 b. Optimization of energy consumption for soybean production using Data Envelopment Analysis (DEA) approach. Applied Energy 88: 3765-3772.
[29] Mobtaker HG, Akram A, Keyhani A. 2012. Energy use and sensitivity analysis of energy inputs for alfalfa production in Iran. Energy for Sustainable Development 16: 84-89.

[30] Singh, S., S. R. Verma and J. P. Mittal, 1997. Energy requirements for production of major crops in India. Agricultural mechanization in Asia, Africa and Latin America, 28 (4): $13-17$

[31] Alam, M. S., M. R. Alam and K. K. Islam, 2005. Energy flow in agriculture: Bangladesh American Journal of Environmental Sciences, 1 (3): 213-220.

[32] Tolga T., Ç. Bahattin and A. Vardar, 2009. An analysis of energy use and input costs for wheat production in Turkey. Journal of Food, Agriculture and Environment., 7 (2): 352356.

[33] Saeed Firouzi and Hashem Aminpanah 2012. Energy Use Efficiency for Groundnut (Arachis hypogaea L.) Production in a Semi-mechanized Cultivation System Annals of Biological $\begin{array}{llll}\text { Research, } 2012, & 3 & \text { (8): } & 3994-3997\end{array}$ http://scholarsresearchlibrary.com/archive.html.

[34] Ozkan B, Fert C, Karadeniz F. 2007. Energy and cost analysis for green house and open-field grape production. Energy 32: 1500-1504.

[35] Pishgar-Komleh S. H., Keyhani A, Rafiee S, Sefeedpari P. 2011. Energy use and economic analysis of corn silage production under three cultivated area levels in Tehran province of Iran. Energy 36: 3335-3341.

[36] Royan M, Khojastehpour M, Emadi B, Mobtaker, H. G. 2012. Investigation of energy inputs for peach production using sensitivity analysis in Iran. Energy Conversion and Management 64: 441-446.

[37] S Shahan, A Jafari, H Mobli, S Rafiee, M KarimiEnergy, Journal of Agricultural Technology, 2008, 4 (1): 77-88.

[38] A Koocheki, R Ghorbani, F Mondani, Y Alizadeh, R Moradi, Int. J. Energy Economics and Policy 2011, 1 (4): 95-106.

[39] E Dagistan, H Akcaoz, B Demirtas, Y Yilmaz, Afric. J. Agric. Res., 2009, 4 (7): 599- 604. 